\title{
Colloquy
}

\section{AMAZONIAN HOUSE-ING: A Visual Anthropology Essay}

\author{
THIAGO DA COSTA OLIVEIRA \\ Ethnologisches Museum Berlin \\ (iD https: / / orcid.org/0000-0003-4546-8806 \\ CARLOS FAUSTO \\ PPGAS-Museu Nacional, Universidade Federal do Rio de Janeiro \\ (iD) https:/ / orcid.org/0000-0002-0617-6643
}

This photo-essay depicts the clash between two modes of dwelling in middle-sized cities in Amazonia: one characteristic of urban and peri-urban areas, and another imposed by resettlements linked to large-scale development projects. The ruins engendered through this mis-encounter reveal the home as an ongoing terrain of contestation, amalgamation, and continuous Amazonization (as Federico Neiburg [2021, this issue] also notes).

Heralded by technocrats and politicians as a milestone for the development of one of Brazil's last frontiers, the Belo Monte Hydroelectric Plant started to be built in 2011 in the state of Pará, amid uproar from ecologists and Indigenous peoples. The third-largest dam in the world entered into operation five years later, flooding some fifty square miles of forest and dramatically altering the seasonal cycle of the Xingu River.

The upriver city of Altamira, where we have been carrying out ethnographic research and artistic collaborations, was directly affected by the flooding and subjected to a massive urban reorganization. ${ }^{1}$ According to official data, about 8,000 of journal content for the above purposes should credit the author and original source. Use, reproduction, or distribution of journal content for commercial purposes requires additional permissions from the American Anthropological Association; please contactpermissions@americananthro.org.DOI:10.14506/ca36.4.06 


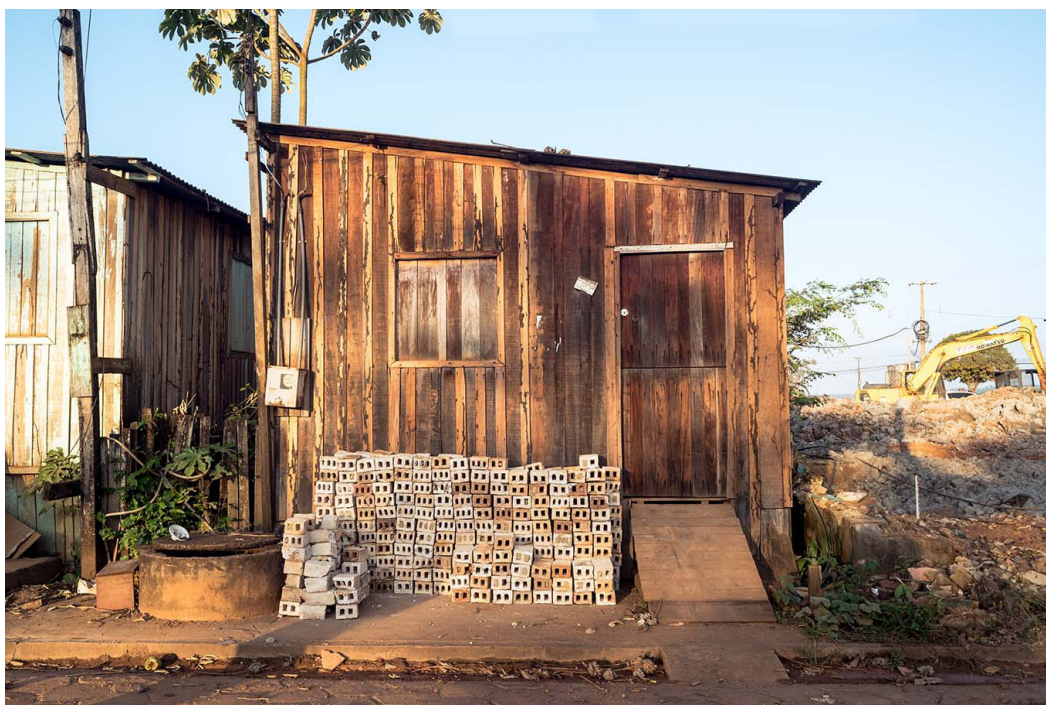

Figure 1. Floodable area in the urban zone of Altamira, Pará, 2015. Photo by Carlos Fausto.

families were removed from their homes, plus another 2,500 families in the rural areas affected by the dam (Azevedo Chaves, Monzoni, and Artuso 2019). Given the intergenerational nature of households and that several nuclear families often share the same domicile, the exact number of people resettled remains unknown.

Until the 1970s, Altamira remained the hub of a network formed by families inhabiting small holdings along the Xingu River, making a living out of fishing, planting, and extractivist activities. With the construction of the Trans-Amazonian Highway at the height of the country's military dictatorship and then the Belo Monte dam forty years later, the municipality's population boomed from 15,000 to 115,000 inhabitants.

Urbanization in middle-sized cities in Amazonia has its own characteristics and does not imply a complete rupture with previous forms of living (Browder and Godfrey 1997; Castro 2009). Amazonian houses always have a garden, linked to subsistence and sociability, which may be complemented by small rural units (WinklerPrins and Souza 2005; Kawa 2020). They are also full of all kinds of useful and (temporarily) unuseful objects, collected according to a logic of bricolage (Lévi-Strauss 1962). The collecting of industrialized objects constitutes both a response to economic vulnerability and a way of making memories with them. Through plants and objects, people weave a meshwork that creates what a house stands for in Amazonia (a house-ing not unlike the mutual ordering of people and objects as described by Ryo Morimoto [2021, this issue]). 


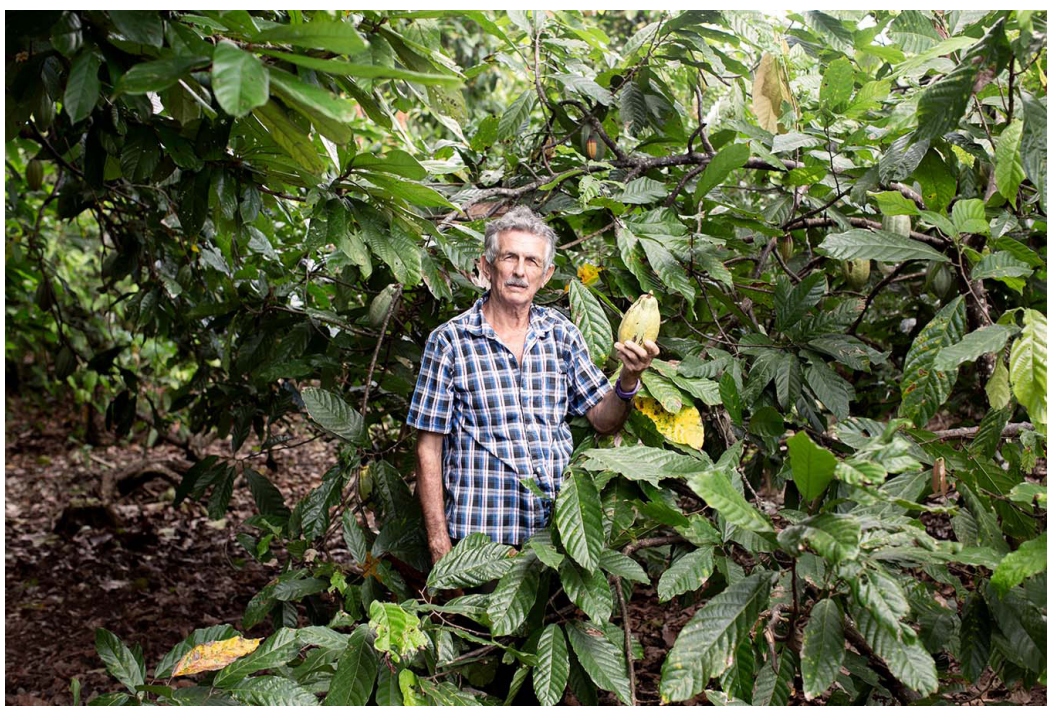

Figure 2. Garden with cocoa tree in a peri-urban zone in Altamira, Pará. Photo by Thiago da Costa Oliveira.

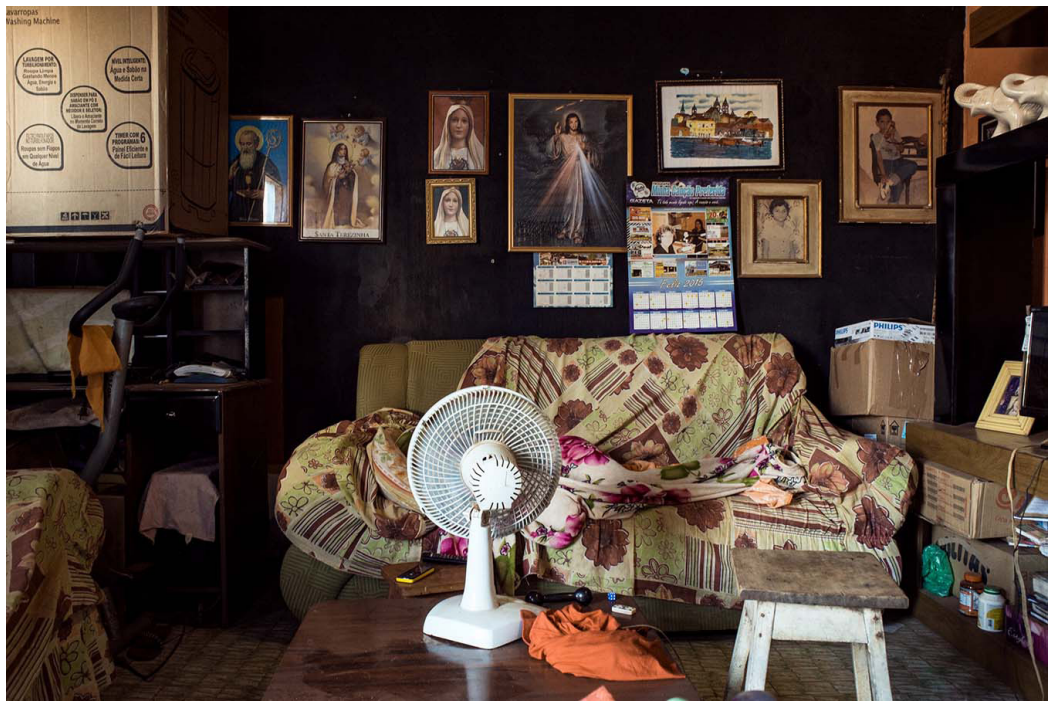

Figure 3. House interior near the port of Altamira, Pará. Photo by Carlos Fausto.

The construction of the Belo Monte dam unraveled the many meshes that constituted the Altamira housing system. This became particularly visible in the annually floodable neighborhoods, where people disassembled their own houses plank by plank, nail by nail, under the scalding sun. Undertaken with relatives and neighbors, this dismantling made visible the networks of sociability integral to the 


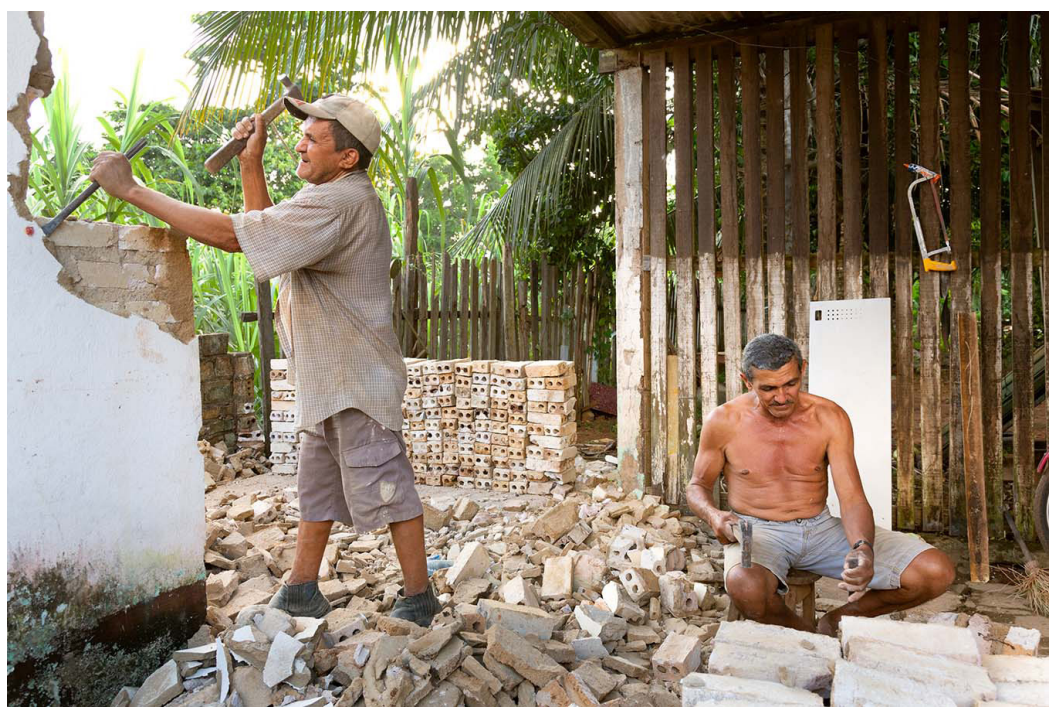

Figure 4. Unbricking an entire house on Perimetral Avenue, Altamira, Pará, 2015. Photo by Carlos Fausto.

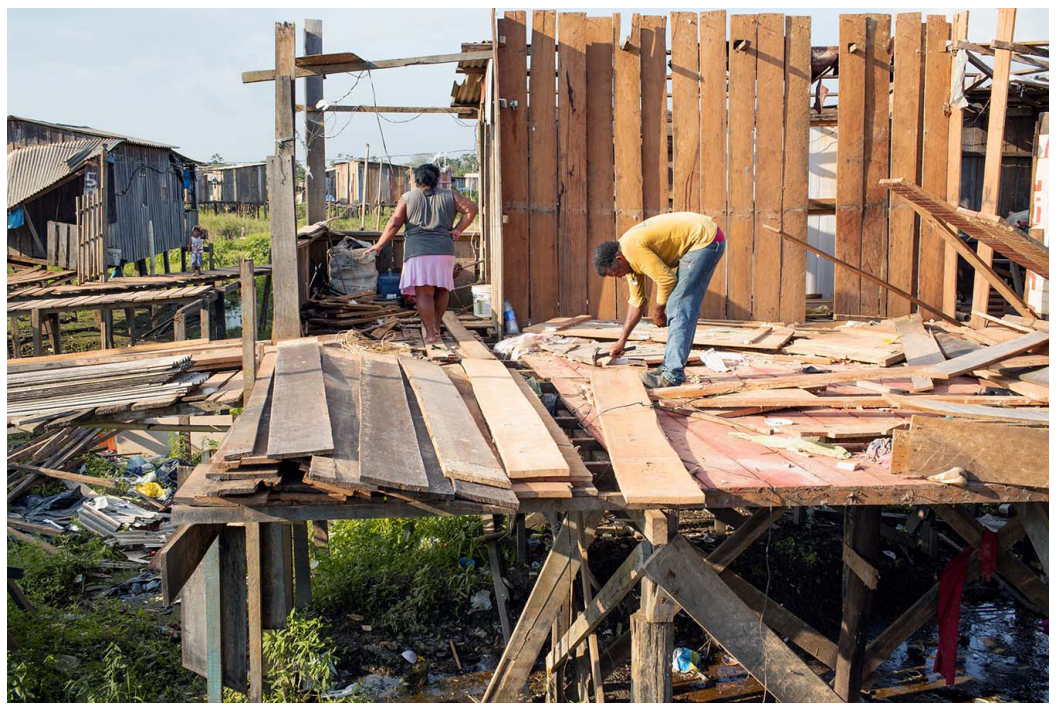

Figure 5. Unnailing houses at Baixão das Olarias, Altamira, Pará. Photo by Carlos Fausto.

home. These peoples would be rehoused in different parts of the city, dispersed from each other, and distant from the main river and its tributaries. Some told us they would, from then on, "live amid strangers."

There is nothing more different from the century-long Amazonian ways of life than the new urban landscape of the resettlement areas. Lines of standardized 


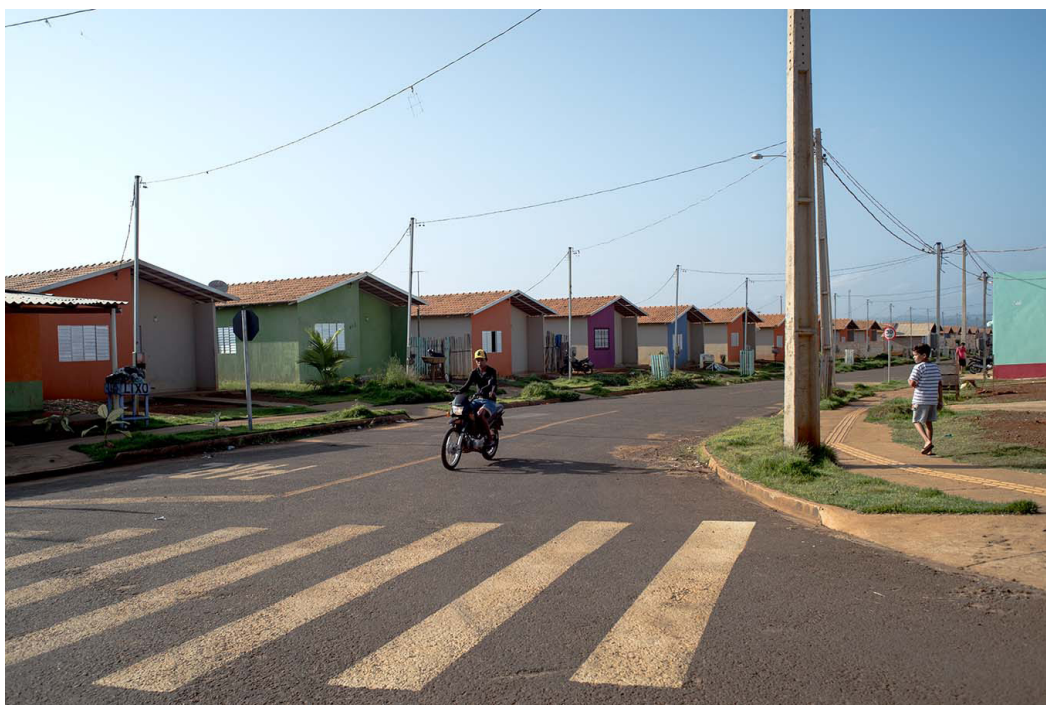

Figure 6. General view of the resettlement neighborhood of Jatobá, Altamira, Pará, 2015. Photo by Thiago da Costa Oliveira.

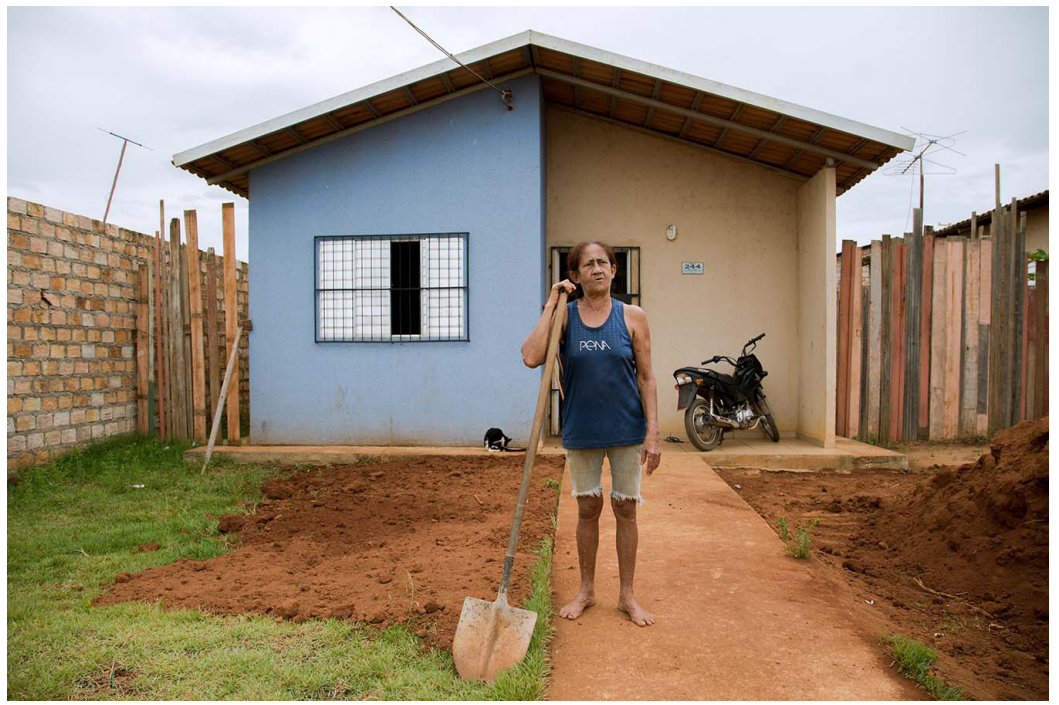

Figure 7. Leveling the front yard in Jatobá, Altamira, Pará, 2016.

Photo by Thiago da Costa Oliveira.

houses, wide sidewalks with no fences, and rectangular geometries all evoke a condominium in the suburbs of a big city. At the same time, precarious sanitation and access to water persisted as problems. The prefabricated walls made it impossible to tie up hammocks - a small "detail" that clashed with a defining feature of living well in Amazonia. 


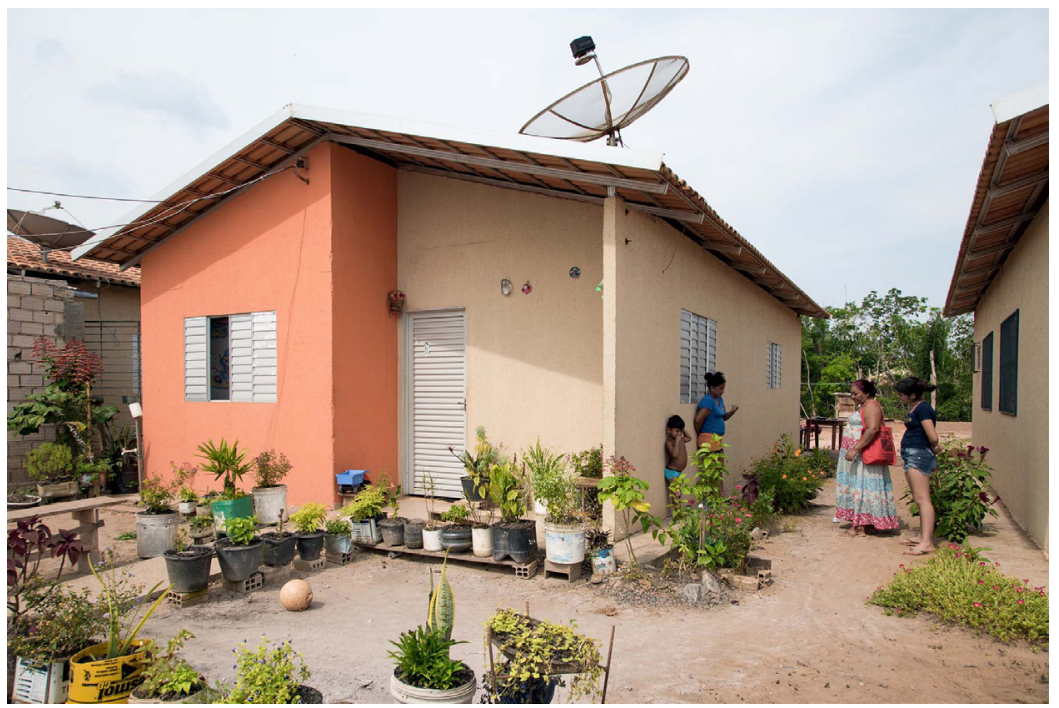

Figure 8. Potted plants in the front yard of a house, Jatobá, Altamira, Pará, 2016. Photo by Thiago da Costa Oliveira.

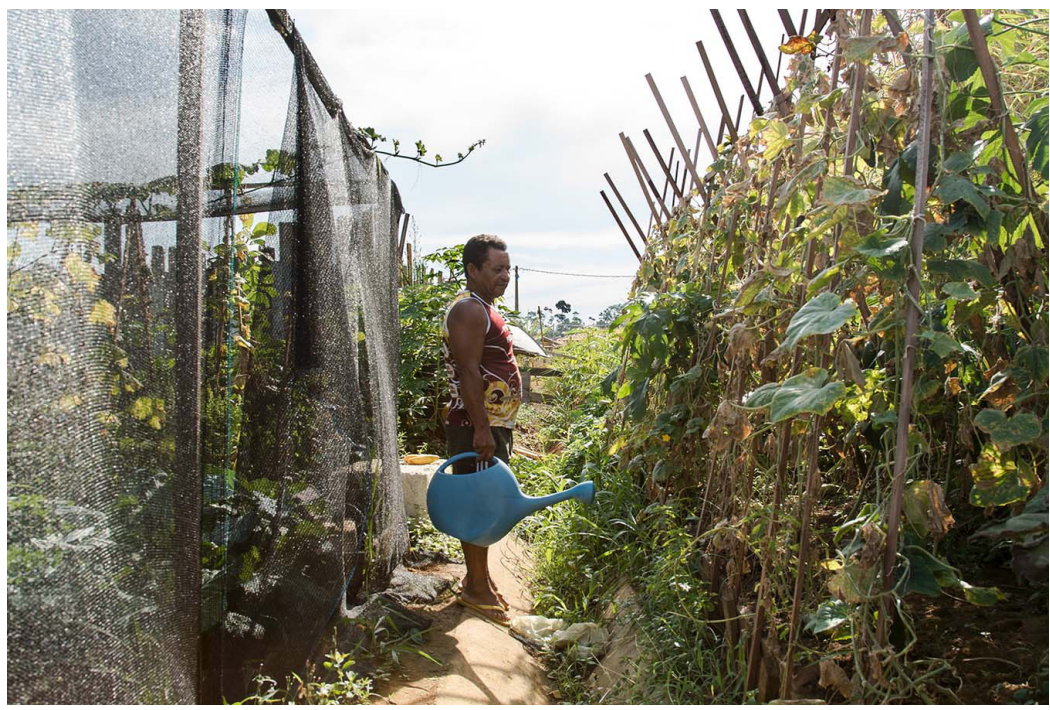

Figure 9. Planting tomatoes in the backyard of a house, Jatobá, Altamira, Pará, 2016. Photo by Thiago da Costa Oliveira.

To cope with these deficiencies, the relocated began to transform the houses using their own repertoires. They fenced backyards, planted new gardens, made chicken coops. Using the remains of the earlier home people had brought along, they also extended the houses to accommodate friends and relatives. At the front of the house, some residents opened small bars, grocery stores, hair salons, and 
tattoo studios, in a pattern common to the region. Using heteroclite materials and their garden-bricolage knowledge, residents thus began to re-Amazonize their houses and everyday lives.

These enlivening techniques gradually subverted the mass-engineering project, revealing an aesthetics of house-ing beyond the assumptions of fixity imagined by those responsible for the reurbanization plan. This aesthetics suggests that the fine balance between environmental specificity and cultural creativity that characterizes the Amazonian human experience still operates far from the forest, knitting its meshes into urban settings.

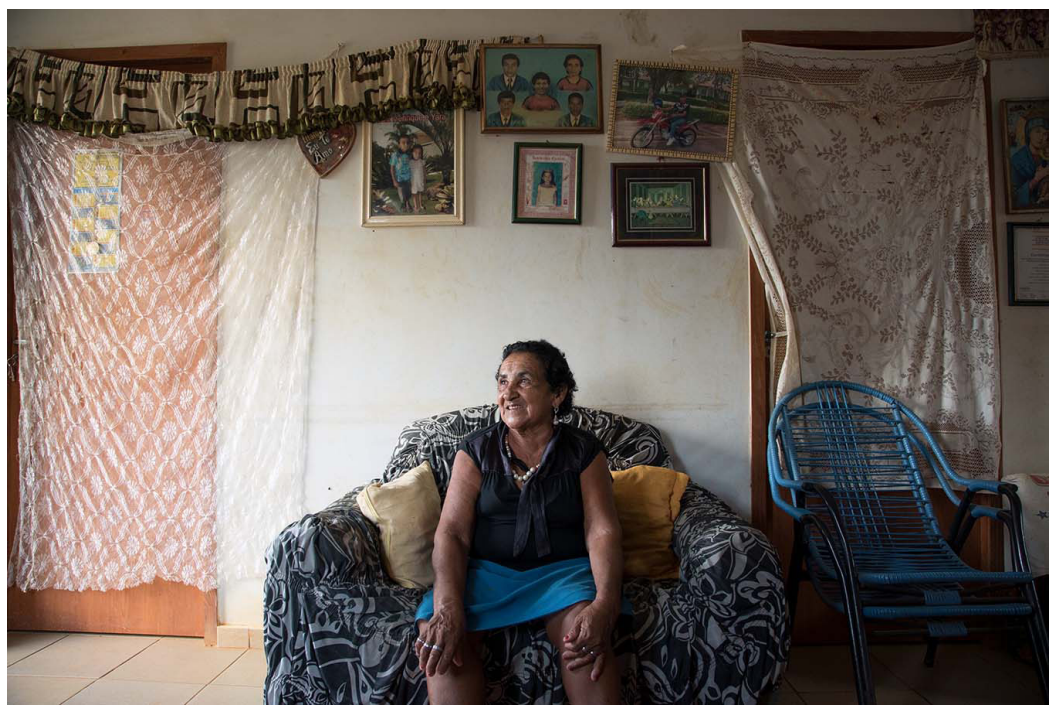

Figure 10. The interior of a house in the resettlement neighborhood of Laranjal, Altamira, Pará. Photo by Thiago da Costa Oliveira.

\begin{abstract}
This visual essay documents the house-ing practices of Amazonian river dwellers and urban and peri-urban residents in the face of large-scale development projects. In Altamira (Pará, Brazil), the construction of the third-largest hydroelectric dam in the world, the Belo Monte Plant, has led to the flooding of housing areas along rivers and the displacement of residents into collective urban resettlements. Although the complexities of people's living did not enter the engineers' calculations or the public policy agenda, the residents improvised construction materials and aesthetic repertoires to preserve the relationships that constituted their local ecologies. Our visual ethnography aims to re-center the situated purview of the resettled, re-visibilizing the house as an index of ineffaceable livelihood and as an ongoing terrain of contestation and continuous Amazonization. [infrastructure and displacement; peri-urban
\end{abstract}


resettlement; Amazonian home; ruins and bricolage; ecology and aesthetics; visual anthropology; Belo Monte dam]

\section{RESUMO}

Este ensaio visual documenta as práticas de house-ing de ribeirinhos e habitantes urbanos e peri-urbanos da Amazônia, confrontados com grandes projetos de desenvolvimento. Em Altamira (Pará, Brasil), a construção da terceira maior hidroelétrica do mundo, a usina de Belo Monte, conduziu ao alagamento de áreas habitacionais e ao deslocamento de seus moradores para novos assentamentos urbanos coletivos. Embora as especificidades do mundo vivido dessas pessoas não tenham entrado no cálculo dos engenheiros, nem na agenda das políticas públicas, os moradores improvisaram materiais construtivos e repertórios estéticos para preservar as relações que constituíam suas ecologias locais. Esta etnografia visual busca restituir a perspectiva situada dos deslocados, dando visibilidade à casa como índice dos modos de viver e como um terreno aberto de contestação e de contínua amazonização. [infraestrutura e deslocamento; reassentamento peri-urbano; casa amazônica; ruínas e bricolagens; ecologia e estética; antropologia visual; usina de Belo Monte]

\section{RESUMEN}

Este ensayo visual documenta las prácticas de house-ing de los ribereños y de los habitantes urbanos y periurbanos de Amazonia que se enfrentan a grandes proyectos de desarrollo. En Altamira (Pará, Brasil), la construcción de la tercera mayor represa hidroeléctrica del mundo, la usina Belo Monte, provocó la inundación de áreas de vivienda y el desplazamiento de sus habitantes a nuevos asentamientos urbanos colectivos. Aunque las especificidades del mundo vivido por estas personas no entraron en los cálculos de los ingenieros ni en la agenda de las políticas públicas, la gente improvisa materiales de construcción y repertorios estéticos para preservar las relaciones que constituían sus ecologías locales. Esta etnografía visual pretende recuperar la perspectiva de los desplazados, dando visibilidad a la casa como índice de formas de vida y como terreno abierto a la permanente contestación y amazonización. [infraestructura y desplazamiento; reasentamiento periurbano; casa amazónica; ruinas y bricolagem; ecología y estética; antropología visual; usina Belo Monte]

\section{NOTES}

Acknowledgments This research was developed with the support of the Programa Nacional de Pós-Doutorado (PNPD) from the Coordenação de Aperfeiçoamento de Pessoal de Nível Superior-Brazil (CAPES) and the Research Fellowship Program CAPES/Humboldt, supported by CAPES and the Alexander von Humboldt Foundation/Germany. It also received support from the Fundação de Amparo à Pesquisa do Rio de Janeiro (Faperj) and the Conselho Nacional de Desenvolvimento Científico e Tecnológico (CNPq). We also thank the several residents of Altamira who opened their homes and shared their stories with us, especially Maria Raimunda dos Santos Lima, Rosa Pessoa, Francisca Josélia de Sousa Amorim, and Edilson Rodrigues de Sousa. 
1. Thiago da Costa Oliveira undertook photographic and filming projects in Altamira from 2015 to 2019. He also collaborated with the Asurini and the Arara peoples in the region. Carlos Fausto conducted fieldwork among the Apyterewa-Parakanã people from 1988 to 1996, returning to the region in 2014 and 2015 to train them in video production. The essay's photographs were taken in 2015, 2016, and 2019.

\section{REFERENCES}

Azevedo Chaves, Kena, Mario Monzoni, and Letícia F. Artuso

2019 "UHE Belo Monte: Reassentamentos rurais, participação social e direito à moradia adequada." Revista Direito GV 15, no. 2: 1-27. https://doi.org/10.1590/23176172201913.

Browder, John O., and Brian J. Godfrey

1997 Rainforest Cities: Urbanization, Development, and Globalization of the Brazilian Amazon. New York: Columbia University Press.

Castro, Edna, ed.

2009 Cidades na Floresta. São Paulo: Annablume.

Kawa, Nicholas C.

2020 "Plants That Keep the Bad Vibes Away: Boundary Maintenance and PhytoCommunicability in Urban Amazonia.” Ethnos 86, no. 2: 228-44. https://doi.org/ 10.1080/00141844.2020.1765830.

Lévi-Strauss, Claude

1962 La pensée sauvage. Paris: Plon.

Morimoto, Ryo

2021 "Home Otherwise: Living Archives and Half-Life Politics in Post-Fallout Coastal Fukushima." Cultural Anthropology 36, no. 4: 573-79. https://doi.org/10.14506/ ca36.4.05.

Neiburg, Federico

2021 "Multiscale Home: Shifting Landscapes and Living-in-Movement in Haiti." Cultural Anthropology 36, no. 4: 548-55. https://doi.org/10.14506/ca36.4.02.

WinklerPrins, Antoinette M.G.A., and Perpetuo S. de Souza

2005 "Surviving the City: Urban Home Gardens and the Economy of Affection in the Brazilian Amazon.” Journal of Latin American Geography 4, no. 1: 107-26. http:// www.jstor.org/stable/25765091. 